\title{
Topsoil Seed Bank as Feeding Ground for Farmland Birds: A Comparative Assessment in Agricultural Habitats
}

\author{
Aikaterini Voudouri, Evgenia Chaideftou (D) and Athanassios Sfougaris * \\ Crop Production and Rural Environment, Laboratory of Ecosystems and Biodiversity Management, \\ Department of Agriculture, University of Thessaly, Fytokou Str., N. Ionia, GR-38446 Volos, Greece; \\ k.voudouri@hotmail.com (A.V.); eugeniachd@gmail.com (E.C.) \\ * Correspondence: asfoug@agr.uth.gr
}

Citation: Voudouri, A.; Chaideftou, E.; Sfougaris, A. Topsoil Seed Bank as Feeding Ground for Farmland Birds: A Comparative Assessment in Agricultural Habitats. Land 2021, 10, 967. https://doi.org/10.3390/ land10090967

Academic Editors: Chiara Piccini and Rosa Francaviglia

Received: 13 August 2021

Accepted: 3 September 2021

Published: 14 September 2021

Publisher's Note: MDPI stays neutral with regard to jurisdictional claims in published maps and institutional affiliations.

Copyright: (c) 2021 by the authors. Licensee MDPI, Basel, Switzerland. This article is an open access article distributed under the terms and conditions of the Creative Commons Attribution (CC BY) license (https:// creativecommons.org/licenses/by/ $4.0 /)$

\begin{abstract}
The topsoil seed bank was studied in four types of agricultural bird habitats: fields with cereals, maize, clover and tilled fields of a Mediterranean plain to determine the potentially richest habitat based on food supply for the wintering farmland birds. The diversity and abundance of topsoil seeds differed between seasons but did not differ significantly between habitats. The cereal habitat was the richest in food supply for the overwintering of farmland birds. The topsoil seed bank was dominated by Chenopodium album, Polygonum aviculare and Amaranthus retroflexus. The findings of this study provide insight for low-intensity management of higher-elevation mount agricultural areas of southern Mediterranean by preserving seed-rich habitats for farmland avifauna.
\end{abstract}

Keywords: topsoil seed bank; farmland bird diet; agricultural ecosystem; biodiversity; habitat

\section{Introduction}

The management of agricultural land has greatly changed over recent decades. This has resulted in different physiognomy and a reduction of agricultural biodiversity and heterogeneity [1-4]. The depletion of the natural transient soil seed bank during cultivation was one of the changes (e.g., [5]). Shifts in agricultural management also led to decline of rural birds [6-13].

Mosaics of low-intensity cultivation in the Mediterranean areas may preserve high diversity of bird species, but intensification or land abandonment probably do not benefit biodiversity $[4,14]$. Reviews identified that agricultural intensification [15] and concomitant abandonment [16] remain the major threat to agricultural ecosystems of the 21st century across Europe and elsewhere (e.g., [17]) with many ecological and biodiversity impairments. As a consequence, investigation of floristic and seed diversity and abundance, along with the physiognomy of the rural landscape, is necessary for identifying the most interesting bird habitats. These habitat features, i.e., high quality or food resources or aboveground floristic components like stubbles or semi-natural with natural habitats suitable for breeding (low intensity farmland with steppe-like vegetation), which can be proved to be beneficial for birdlife per case facilitate biodiversity maintenance $[6,18]$.

Approximately $30 \%$ of the bird species being "Species of European Conservation Concern" exploit agricultural ecosystems $[19,20]$. In rural landscape across Europe, food availability (plant and seed food items) is reduced especially during winter [3,21], and nesting habitats in spring are deficient for many bird species that have declined over recent decades [22]. For instance, seed-eating birds face the risk of limited accessibility to preferred seeds when vegetation is dense in uncultivated areas close to farmlands [23] or they feed in stubble of reduced quality due to modernized techniques in cereals harvested as arable silage [24].

Especially in winter the most important food resource in the rural landscape for birds is the soil seed bank (e.g., $[3,25]$ ). However, research has been focused on the impacts of agricultural practices on the seed bank composition, abundance and vertical distribution of 
weeds in the rural landscape regarding their persistence (e.g., [26]), fertilization (e.g., [27]) crop rotation or varied tillage systems (e.g., [28,29]). As a result, the seed bank fraction on topsoil of agricultural habitats that serves as food resource to bird seed-eaters is rarely, if at all, studied.

Food resource provision [30] is crucial for wintering seed-eaters especially them of a high conservation interest. However, it is less studied in the Mediterranean regions compared to northern Europe. For conservation of bird populations which are exclusively or partially seed foragers, such as Passer montanus (Eurasian tree sparrow), P. domesticus (house sparrow), Fringilla coelebs (common chaffinch), Carduelis chloris (European greenfinch), C. carduelis (European goldfinch), Miliaria calandra (corn bunting), Turdus merula (common blackbird) and Emberiza spp. (bunting birds), a precise "instruction" of the most proper habitat, i.e., seed-rich in winter [31], is not yet defined [32].

A seed-eating bird may have preference on the seeds of particular plant species for their diet $[3,22]$ thus seed consumption can cause seed limitation of these particular species. As a result, determination of the value a habitat carries to supply winter food to birds [33] is critical in decision-making for maintaining diversity in agricultural ecosystems $[21,34,35]$. Therefore, there is scope for further consideration of how we manage areas of former traditional low-intensity agriculture in Europe, supported by European subsidies [24], and principally seed-rich habitats such as cereal stubbles in certain seasons of the year (e.g., $[36,37])$.

This study aimed at determining the potentially richest habitat (for food supply) for the wintering of rural avifauna in the Dolichi plain of Elassona region. To this aim, the study investigated the effect of the type of crop (habitat for birds) on the topsoil seed bank in four arable fields undergoing post-dispersal consumption of seeds by farmland birds. This topsoil seed bank entails a fraction that serves as food source especially to the seed-eaters.

\section{Materials and Methods}

\subsection{Study Area}

The study area covers an area of $40 \mathrm{~km}^{2}$, where the settlement of Dolichi and the municipality of Livadi are situated. Livadi is located at an altitude of $1100 \mathrm{~m}$. Dolichi lies $5 \mathrm{~km}$ from the foothills of Mount Olympus and $21 \mathrm{~km}$ from Elassona, at an altitude of $590 \mathrm{~m}$ asl. The inhabitants of Dolichi, numbering 473 (in 2001) are principally involved in land cultivation and animal husbandry.

The settlement of Dolichi is located in the center of a cultivated plain and is surrounded by hilly and mountainous natural ecosystems. The main crops are cereals, with wheat (Triticum sp.) dominating over the barley (Hordeum sp.). Previously, the second largest crop was tobacco, but due to the regime of European subsidies tobacco cultivation was abandoned, therefore the second rank is currently held by maize crops (Zea mays). Legumes and vegetables are cultivated on a smaller scale. Clover (Trifolium sp.) in particular is cultivated in a mixed agricultural-livestock farming system. In 2005, vetch crops exceptionally dominated due to compulsory crops rotation in line with the Codes of Good Agricultural Practice. Ecosystems with a high plant cover such as grasslands, hedgerows, uncultivated vegetation strips and riparian zones are largely present in the area. The cultivation system is mechanized, but clearly less intensive than the one of the main plain of Thessaly. In the area many plantations of locust (Robinia pseudoacacia) have been established through subsidies of the agri-environmental measure "Afforestation of agricultural land".

The landscape characteristics in this area were appropriate for the research. Approximately two thirds $(2 / 3)$ of the study area are covered by anthropogenic ecosystems and only one third by natural ecosystems. Among natural ecosystems, grasslands (including ecotones) hold the largest area. Cereals comprise $90 \%$ of anthropogenic ecosystems while legumes only $5 \%$. The remaining $5 \%$ is covered by other types of agricultural ecosystems. In this area of study, fields are undergoing post-dispersal consumption of seeds by farmland birds, having thus a potential as feeding sources to them, with non-cultivated 
and cultivated plant species ([38]; Table A1 of Appendix A). The study took place in four selected habitat types which actually are arable cropped fields: cereals, maize, clover and tillage, with average surface area of $2.35 \pm 0.3$ ha ([38]; Table A2 of Appendix A). According to [38], within this area the above-ground non-cultivated species richness and (\%) plant cover differed from the respective ones of plant species serving as food sources to farmland birds among the four studied habitats (Table A2). This is not true though for the field physiognomy (see Table A2).

The avian diversity in this area was also proper for the research aims. Overall, 33 bird species were recorded in the study area (unpublished data, see Table A3 in Appendix A). A high majority, that is, 26 bird species comprising $79 \%$ of the recorded bird species in the study area, are classified as seed-eaters and all birds listed in Table A3 are present in all studied habitat types (namely the crop types: cereals, maize, clover and tillage).

\subsection{Research Design}

The sampling area is shown in Figure 1. Four types of fields were sampled and analyzed between September 2006 and March 2007 in the current study: cereals, maize, clover and tillage (bare soil during winter). Since these fields include 'micro-sites' providing refuge and food resources to rural bird populations, they are referred to here as "habitats". There were crops and stubbles in the maize and cereal fields during winter.

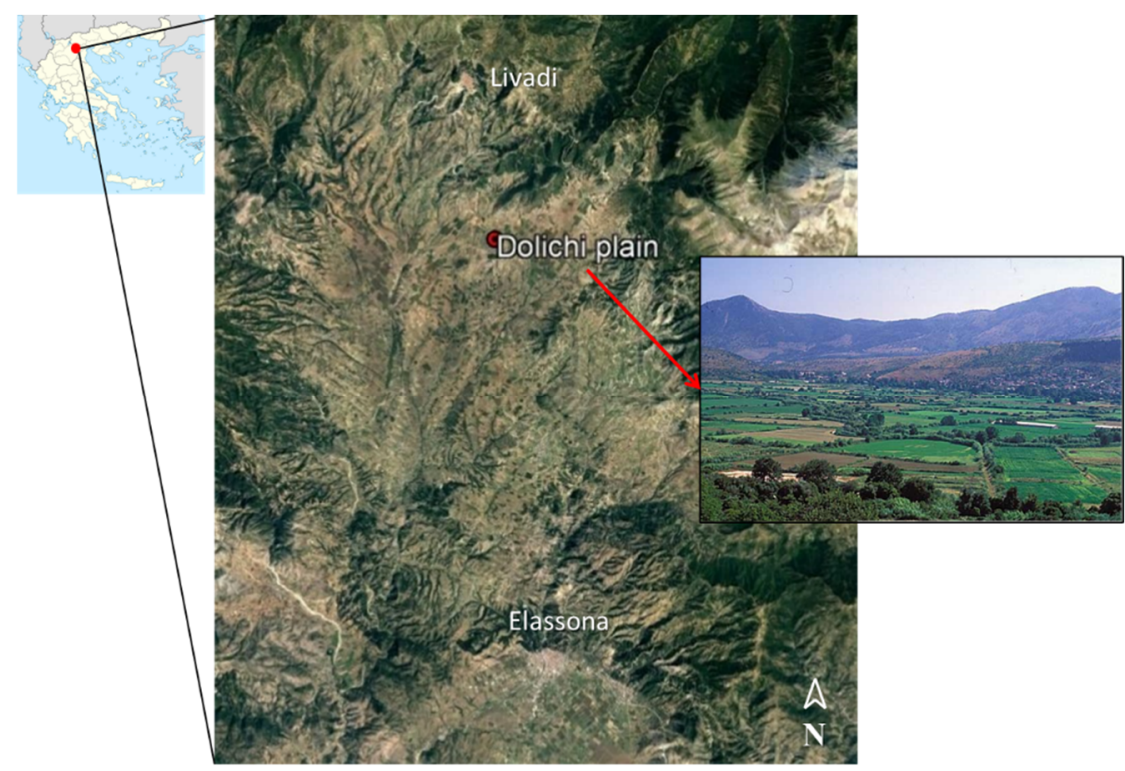

Figure 1. Map of Dolichi plain in the area of Elassona (study area). Image and photo sources: The blank map of Greece (on the top left) is by Lencer, CC BY-SA 3.0, https: / / commons.wikimedia.org/ $\mathrm{w} /$ index.php?curid $=4432468$. The satellite map image is extracted and edited from Google Earth (https: / / earth.google.com/) on 22 November 2017. The landscape photo of the Dolichi plain is taken from [38].

Plots of approximately $20 \mathrm{~m}^{2}$ each were randomly chosen so that the major species are represented in the cultivated area. A total of 36 plots, in total $846.7 \mathrm{~m}^{2}$, were recorded and sampled. The number of studied plots ( $\mathrm{n}$ ) per crop type was: $\mathrm{n}=10$ in winter cereal fields $\left(197.5 \mathrm{~m}^{2}\right), \mathrm{n}=10$ in maize fields $\left(274.5 \mathrm{~m}^{2}\right), \mathrm{n}=6$ in clover fields $\left(171.5 \mathrm{~m}^{2}\right)$ and $\mathrm{n}=10$ in tillage $\left(203.2 \mathrm{~m}^{2}\right)$ (Table A4).

\subsection{Topsoil Seed Bank Sampling, Seed Extraction and Identification}

During fall-end and winter-start of 2006, within 21 plots (cereal $n=6$, maize $n=6$, clover $n=3$ and tillage $n=6$ ) randomly selected out of the total of 36 , soil cores were sampled (soil corer of $15 \mathrm{~cm}$ diameter, and $1 \mathrm{~cm}$ depth). In randomly selected plots (at every second measurement of plant cover), 10 soil samples were collected $(R=10)$ across the 
diagonal of the plot and were placed into encoded polyethylene bags that were transferred to the laboratory. The second soil core sampling took place in spring of 2007 following exactly the same protocol, though the number of plots differed due to the seasonal change of landscape in Dolichi plain. A total of 12 plots were totally studied in spring: cereal $(\mathrm{n}=4)$, maize $(\mathrm{n}=2)$, clover $(\mathrm{n}=3)$ and tillage $(\mathrm{n}=3)$. Seeds up to one centimeter of soil depth have been sampled. Therefore, the seeds and seed bank are referred in this article as 'topsoil'.

Soil core samples were retained at $4{ }^{\circ} \mathrm{C}$ for $24 \mathrm{~h}$ to avoid seed germination. Then seeds were isolated from soil phase using sieves and were identified at species level in petri dishes under stereoscope and magnifying lens using a series of keys (Appendix B). In addition, plant specimens were collected in spring and autumn of 2006 so that all plant species the seeds of which are potentially present in the topsoil seed bank of autumn 2007, are included in a reference plant collection that facilitated the seed identification (sources are listed in Appendix B). Classification of plant species on the basis of their significance to the farmland bird diet is presented in Tables A1 and A5 of Appendix A.

\subsection{Data Analysis}

The species richness of the seed bank was estimated as the number of species per $\mathrm{m}^{2}$. The Shannon index (entropy) was also estimated for the topsoil seed bank. The seed abundance of the topsoil seed bank was estimated as the average number of seeds per square meter $\left(\mathrm{m}^{2}\right)$.

The Shannon index (entropy) and the seed abundance of the topsoil seed bank were tested by estimating the differences between habitats (cereal, maize, clover and tillage) and seasons (winter and spring) using generalized linear mixed (GLM) effect models. For Shannon index, the GLM for Gaussian family with random intercept of plot were used. For seed abundance, the GLM for Poisson family (with log link function) with random intercept of plot were employed. For model selection, model with and without interaction between season and habitat were compared with simple generalized linear model (for Gaussian family in the case of Shannon Index; for Poisson family (with log link function) in the case of seed abundance). In each case, all three models were compared using $p$-value of ANOVA and Akaike Information Criterion (AIC). Signs of heteroscedasticity (residuals vs. fitted plot) and normality of residuals (q-q plot) were also tested for identifying the best performing model. Overdispersion of the Poisson model was also checked and, if needed, the analysis was reconducted using generalized linear (simple or mixed effect) model with negative-binomial family with log link function.

Predictions were generated with and without inclusion of random effects. The $95 \%$ confidence intervals were estimated with bootstrapped simulation $(n=1000)$ using the bootMer function. Post-hoc (Tukey all-pairs) comparisons were conducted.

The data were processed in R 4.1.0 [39] using the packages: broom.mixed [40], dplyr [41], ggplot2 [42], lme4 [43], lmerTest [44], MASS [45], multcomp [46], and tidyr [47].

\section{Results}

\subsection{Composition of the Topsoil Seed Bank as Food Source to Farmland Birds}

Overall, the soil seed bank sampling and seed identification resulted in a total of 66 plant species, 64 of which are non-cultivated and the other two are the cultivated species Triticum aestivum and Zea mays. Out of these 66 plant species, 49 species were classified as having a level of significance as food items to the farmland birds (Table A5).

Soil seed bank sampling during winter in 36 fields resulted in a total of 62 plant species, 15 of which were present in all habitats while the soil seed bank sampling during spring in 12 fields resulted in 39 identified species. A total of 26 and 21 species of seeds serving as food source to farmland avifauna were identified in winter and spring topsoil seed bank, respectively (Table A5).

The highest number of species with significance as food sources to birds was recorded in cereals ( 34 species) while the lowest in tillage ( 23 species) (see Table A5). The habitats 
can be ranked on the basis of the number of significant species in serving as food sources to birds as follows: tillage (23) < clover $(25)<$ maize (31) < cereal (34).

The winter seed bank was dominated in all studied habitats by Chenopodium album, Polygonum aviculare and Amaranthus retroflexus. The last two species also dominated the spring seed bank. Apart from these two species, the following species predominated in the spring seed bank: Lithospermum arvense in cereals, Amaranthus albus in maize, Echinochloa crus-galli in clover and Digitaria sanguinalis in tillage (Table A5).

Commonly, 35 species were present in both spring and winter while only seven species (Brassica juncea, Sinapis arvensis, Silene dioica, Chenopodium album, Polygonum aviculare, Portulaca oleracea, Amaranthus retroflexus) were present in all habitats in both seasons (Table A5).

These common and dominant plant species, with the exception of Amaranthus sp. and P. oleracea, are classified to highest significance as food sources to farmland birds (Table A5).

\subsection{Shannon Entropy and Seed Abundance of the Topsoil Seed Bank}

\subsubsection{Model Selection}

Mixed effect model without interaction did not differ significantly from model with interaction for both seed abundance and Shannon index (entropy). However, it differed in both cases significantly from model without random intercept. The model without interaction also performed best in terms of AIC in the case of seed abundance, and similar to model with interactions in the case of Shannon entropy. Visual inspection showed no clear signs of heteroscedasticity nor deviation from normality of residuals.

However, in the case of seed abundance, the model showed significant overdispersion (dispersion ratio $=12.97$, Pearson's Chi-Squared $=2931.16, p<0.001$ ). Thus, instead of using Poisson family model, negative binomial family was used for model estimation. The new model also performed better in case of AIC (Tables 1 and 2). Visual inspection showed that normality of residuals was slightly worse than in Poisson family model.

Table 1. Generalized Linear Model comparison for Shannon entropy and seed abundance in the topsoil seed bank.

\begin{tabular}{|c|c|c|c|c|c|c|}
\hline \multicolumn{7}{|c|}{ Shannon Entropy } \\
\hline $\begin{array}{l}\text { Variable contrast } \\
\text { season + habitat }\end{array}$ & $\begin{array}{l}\text { npar } \\
6\end{array}$ & $\begin{array}{c}\log \operatorname{Lik} \\
-127.29\end{array}$ & $\begin{array}{c}\text { deviance } \\
254.57\end{array}$ & Chisq & Df & $\operatorname{Pr}(>$ Chisq $)$ \\
\hline $\begin{array}{l}\text { season }+ \text { habitat }+ \\
\quad(1 \mid \text { plots })\end{array}$ & 7 & -121.41 & 242.83 & 11.7466 & 1 & $0.0006095^{* *}$ \\
\hline $\begin{array}{l}\text { season } * \text { habitat }+ \\
(1 \mid \text { plots })\end{array}$ & 10 & -118.27 & 236.53 & 6.2956 & 3 & 0.0980824 \\
\hline \multicolumn{7}{|c|}{ Seed Abundance } \\
\hline $\begin{array}{l}\text { Variable contrast } \\
\text { season }+ \text { habitat }\end{array}$ & $\underset{6}{\operatorname{npar}}$ & $\begin{array}{c}\log \operatorname{Lik} \\
-1099.8\end{array}$ & $\begin{array}{c}\text { deviance } \\
2199.5\end{array}$ & Chisq & Df & $\operatorname{Pr}(>$ Chisq $)$ \\
\hline $\begin{array}{l}\text { season }+ \text { habitat }+ \\
\quad(1 \text { plots })\end{array}$ & 7 & -1054.5 & 2109 & 90.5848 & 1 & $<2 \times 10^{-16 * *}$ \\
\hline $\begin{array}{l}\text { season * habitat }+ \\
(1 \mid \text { plots })\end{array}$ & 10 & -1053.5 & 2107.1 & 1.8701 & 3 & 0.5998 \\
\hline
\end{tabular}

+ indicates it is additive model $\left(\mathrm{y}=\right.$ spring + winter + tillage + clover + maize + cereals). ${ }^{*}$ indicates there is interaction between habitat and season $(\mathrm{y}=$ spring + winter + tillage + clover + maize + cereals + spring $*$ tillage + spring ${ }^{*}$ clover + spring $*$ maize + spring $*$ cereals + winter $*$ tillage $) .{ }^{* *}$ indicates statistical significance, $p<0.05$. 
Table 2. Generalized Linear Model comparison for Shannon entropy and seed abundance in the topsoil seed bank on the basis of AIC.

\begin{tabular}{ccc}
\hline & Shannon Entropy & \\
\hline Variable contrast & $\mathrm{df}$ & AIC \\
season + habitat & 6 & 2211.542 \\
season + habitat $+(1$ | plots $)$ & 7 & 2122.957 \\
season * habitat + (1 | plots) & 10 & 2127.087 \\
\hline & Seed Abundance & \\
\hline Variable contrast & $\mathrm{df}$ & AIC \\
season + habitat & 6 & 2211.542 \\
season + habitat + (1 | plots $)$ & 7 & 2122.957 \\
season * habitat + (1 | plots $)$ & 10 & 2127.087 \\
\hline
\end{tabular}

+ indicates it is additive model. ${ }^{*}$ indicates there is interaction between habitat and season.

The calculated parameters of the model for Shannon entropy and seed abundance are summarized in Table 3.

Table 3. Model summary for Shannon entropy and seed abundance.

\begin{tabular}{|c|c|c|c|c|c|c|c|c|}
\hline \multicolumn{9}{|c|}{ Shannon Entropy } \\
\hline Effect & Term & Estimate & Std. Error & Statistic & $\mathrm{df}$ & $p$ Value & Conf. Low & Conf. High \\
\hline fixed & (Intercept) & 4.713 & 0.442 & 16.516 & 34.476 & $6.01 \times 10^{-18}$ & 3.921 & 5.665 \\
\hline fixed & Season winter & 0.874 & 0.080 & -1.462 & 38.114 & 0.152 & 0.731 & 1.047 \\
\hline fixed & Habitat Clover & 1.019 & 0.121 & 0.157 & 27.754 & 0.876 & 0.807 & 1.287 \\
\hline fixed & Habitat Maize & 0.877 & 0.095 & -1.211 & 26.078 & 0.236 & 0.709 & 1.085 \\
\hline fixed & Habitat Tillage & 0.861 & 0.096 & -1.341 & 32.468 & 0.189 & 0.692 & 1.071 \\
\hline \multicolumn{9}{|c|}{ Seed Abundance } \\
\hline Effect & Term & Estimate & Std. Error & Statistic & & $p$ Value & Conf. Low & Conf. High \\
\hline fixed & (Intercept) & 72.366 & 18.403 & 16.837 & & $1.30 \times 10^{-63}$ & 43.962 & 119.123 \\
\hline fixed & Season winter & 0.434 & 0.106 & -3.415 & & 0.001 & 0.268 & 0.700 \\
\hline fixed & Habitat Clover & 1.444 & 0.485 & 1.093 & & 0.275 & 0.747 & 2.789 \\
\hline fixed & Habitat Maize & 1.061 & 0.327 & 0.190 & & 0.849 & 0.579 & 1.942 \\
\hline fixed & Habitat Tillage & 0.600 & 0.182 & -1.679 & & 0.093 & 0.331 & 1.089 \\
\hline
\end{tabular}

\subsubsection{Shannon Entropy of the Topsoil Seed Bank}

The Shannon entropy of the topsoil seed bank did not differ significantly between seasons or between habitats (Table 4).

Table 4. Tukey all-pairs comparisons for Shannon entropy of the topsoil seed bank.

\begin{tabular}{ccccccc}
\hline \multirow{2}{*}{ Term } & Post-Hoc Comparisons & & \\
& Contrast & $\begin{array}{c}\text { Null. } \\
\text { Value }\end{array}$ & Estimate & $\begin{array}{c}\text { Std. } \\
\text { Error }\end{array}$ & Statistic & Adj. $\boldsymbol{p}$ Value \\
\hline \multirow{2}{*}{ Season } & Winter-Spring & 0 & -0.134 & 0.092 & -1.461 & 0.144 \\
& Clover-Cereals & 0 & 0.019 & 0.119 & 0.157 & 0.999 \\
& Maize-Cereals & 0 & -0.131 & 0.108 & -1.211 & 0.619 \\
& Tillage-Cereals & 0 & -0.149 & 0.111 & -1.342 & 0.535 \\
& Maize-Clover & 0 & -0.150 & 0.126 & -1.188 & 0.633 \\
& Tillage-Clover & 0 & -0.168 & 0.128 & -1.311 & 0.554 \\
& Tillage-Maize & 0 & -0.018 & 0.117 & -0.154 & 0.999 \\
\hline
\end{tabular}

In spring, the estimated Shannon entropy was higher in cereal than in the other three habitats; while in maize it was the lowest (Table 5). However, these differences were not statistically different. 
Table 5. Model predictions compared to Shannon entropy (mean and median) of the topsoil seed bank.

\begin{tabular}{llcccc}
\hline Habitat & Season & $\begin{array}{c}\text { Mean } \\
\text { Shannon Entropy }\end{array}$ & $\begin{array}{c}\text { Median } \\
\text { Shannon Entropy }\end{array}$ & $\begin{array}{c}\text { Prediction } \\
\text { Adjusted }\end{array}$ & $\begin{array}{c}\text { Predicted } \\
\text { Unadjusted }\end{array}$ \\
\hline Cereals & spring & 1.69 & 1.63 & 1.63 & 1.55 \\
Cereals & winter & 1.34 & 1.39 & 1.37 & 1.56 \\
Clover & spring & 1.53 & 1.58 & 1.56 & 1.42 \\
Clover & winter & 1.47 & 1.63 & 1.46 & 1.40 \\
Maize & spring & 1.08 & 1.20 & 1.29 & 1.42 \\
Maize & winter & 1.35 & 1.37 & 1.32 & 1.43 \\
Tillage & spring & 1.43 & 1.44 & 1.41 & 1.28 \\
Tillage & winter & 1.21 & 1.31 & 1.22 & 1.27 \\
\hline
\end{tabular}

Table 5 presents the model predictions, both unadjusted (not including random effect) and adjusted (including random effect), compared to the original-data mean and median.

\subsubsection{Seed Abundance of the Topsoil Seed Bank}

Significant differences in the seed abundance of the topsoil seed bank were observed only between seasons (winter-spring; see Post-Hoc comparisons in Table 6). In tillage the seed abundance was lower than in the other three habitats, and this difference was more pronounced with clover (Table 7). It is noted, however, that these differences in the seed abundance between habitats were insignificant and this is also confirmed by the Post-Hoc comparisons (Table 6).

Table 6. Tukey all-pairs comparisons for seed abundance of the topsoil seed bank.

\begin{tabular}{ccccccc}
\hline \multirow{2}{*}{ Term } & & \multicolumn{7}{c}{ Post-Hoc Comparisons } \\
& Contrast & $\begin{array}{c}\text { Null. } \\
\text { Value }\end{array}$ & Estimate & $\begin{array}{c}\text { Std. } \\
\text { Error }\end{array}$ & Statistic & Adj. $\boldsymbol{p}$ Value \\
\hline \multirow{2}{*}{ Season } & Winter-Spring & 0 & -0.835 & 0.245 & -3.415 & $0.0006^{*}$ \\
& Clover-Cereals & 0 & 0.367 & 0.336 & 1.093 & 0.693 \\
& Maize-Cereals & 0 & 0.059 & 0.309 & 0.190 & 0.997 \\
& Tillage-Cereals & 0 & -0.510 & 0.304 & -1.679 & 0.334 \\
& Maize-Clover & 0 & -0.308 & 0.356 & -0.867 & 0.821 \\
& Tillage-Clover & 0 & -0.877 & 0.350 & -2.505 & 0.059 \\
& Tillage-Maize & 0 & -0.569 & 0.320 & -1.775 & 0.284 \\
\hline
\end{tabular}

* indicates statistical significance, $p<0.05$.

Table 7. Model predictions compared to seed abundance (mean and median) of the topsoil seed bank.

\begin{tabular}{lccccc}
\hline Habitat & Season & $\begin{array}{c}\text { Mean } \\
\text { Seed Abundance }\end{array}$ & $\begin{array}{c}\text { Median } \\
\text { Seed Abundance }\end{array}$ & $\begin{array}{c}\text { Prediction } \\
\text { Adjusted }\end{array}$ & $\begin{array}{c}\text { Predicted } \\
\text { Unadjusted }\end{array}$ \\
\hline Cereals & spring & 89.7 & 87 & 87.7 & 72.4 \\
Cereals & winter & 41.5 & 28 & 39.6 & 31.4 \\
Clover & spring & 96.5 & 90 & 96.9 & 104.5 \\
Clover & winter & 52.7 & 45 & 51.9 & 45.3 \\
Maize & spring & 125.3 & 104.5 & 111.1 & 76.7 \\
Maize & winter & 35.1 & 26 & 34.5 & 33.3 \\
Tillage & spring & 37.2 & 37 & 38.6 & 43.4 \\
Tillage & winter & 22.1 & 12 & 19.7 & 18.8 \\
\hline
\end{tabular}

Table 7 shows the model predictions, both unadjusted (not including random effect) and adjusted (including random effect), compared to the original-data mean and median. 


\section{Discussion}

\subsection{Effect of Habitat (Crop) Type on the Topsoil Seed Bank}

The differences in Shannon entropy of the topsoil seed bank were insignificant for the tested samples of this study. The effect of habitat (crop) type in such landscapes require, to our view, further coordinated research that would also include samples of different size, and consideration of a soil-property matrix [29].

The winter and spring Shannon entropy were lower in tillage though not significantly. This difference, although insignificant, could be explained by the widespread practice of autumn tillage which buries the surface seeds [48] thus reducing their availability in fields [49]. Tillage techniques prevent vegetation growth, seed germination and seedling growth [50] and temporarily enrich the topsoil with seeds [51]. Topsoil seeds are easily depleted from the soil surface also because they are consumed by high numbers of birds using stubbles as feeding grounds [52]. Moreover, in all studied fields where tillage was employed the seed abundance of dominant species was very high, as tillage decrease seed diversity [53]. [29] stressed the significance of such practices to preserve biodiversity in crop fields, and the complexity of it, as continuous tillage was found to have increased the soil seedbank diversity and density under specific soil conditions.

The winter topsoil seed bank is dominated only by Chenopodium album, Polygonum arviculare and Amaranthus retroflexus that have long-lived seeds according to [54]. By contrast, the spring topsoil seed bank reveals a different picture since apart from Chenopodium album, and Amaranthus retroflexus, four other species are prominently present: Lithospermum arvense, Amaranthus albus, Echinochloa crus-galli and Digitaria sanguinalis in cereal, maize, clover and tillage respectively. The above species, apart from Lithospermum arvense, are also reported to have seeds of high longevity [54]. However, note that the seeds of Echinochloa crus-galli found in clover and Digitaria sanguinalis found in tillage in our case, are classified as very-short lived for untilled systems by [55].

Since in this study only the topsoil seed bank has been investigated, no conclusion on seed persistence per species under heavy disturbance can be given. Regarding seed availability as food sources to farmland birds it should be considered that in no- or lowtillage fields where the soil is not heavily disturbed, seed predation is enhanced [56,57].

In this study, the genus Amaranthus dominated [58] maize crops. Chenopodium album dominated the topsoil seed bank of all habitats either in spring or in winter. This is consistent with the findings of [59], who detected high seed abundances of this annual broadleaved species in the upper $5 \mathrm{~cm}$ of soil irrespective of barley tillage treatments in Alaska, as well as of other authors [58,60]. Polygonum arviculare was dominant in winter in the topsoil seed bank, implying that autumn tillage did not bury the bulk of its surface seeds. [59] detected higher seed density of Polygonum arviculare, only for medium-intensity tillage treatments (disc once) in the upper $5 \mathrm{~cm}$ of soil.

Ref. [61] found in fields of Poland that the base of the winter diet of reed bunting Emberiza schoeniclus are seeds of Chenopodium album, Amaranthus retroflexus, Setaria viridis, Stellaria media and Fumaria officinalis. It should be underlined that the aforementioned differences in dominant seeds are consistent with the high spatial variability of seeds predated, such as Chenopodium album, given that some birds of the study area may count on alternate food resources, have preference to specific species and respond differently to different plant cover [62] and landscape composition in winter [35].

Species present in the aboveground flora and linked to disturbance in agricultural soils are Amaranthus spp., Chenopodium album and Echinochloa crus-galli, while Digitaria sanguinalis, of which seeds were dominant in clover, are linked to undisturbed soils [54] and these species have over 3-year seed longevity [54].

\subsection{Agricultural Habitats with a Topsoil Seed Bank Serving as Food Source to Farmland Birds}

A total of 26 and 21 species of seeds serving as food source to farmland avifauna were identified in winter and spring, respectively. Differences between spring and winter seed abundance are mostly attributed to seed consumption of species with high significance 
to farmland bird diet in this study. The farmland birds use stubbles more frequently in winter $[63,64]$. The main food source of seed-eating birds during winter is the soil seed bank $[3,22,25,65]$.

Cereal seeds would rather show a higher potential to positively impact rural bird diversity in the studied landscape, while the structural characteristics in clover habitats might also favor birds' presence, but these are objectives of future study in a more systems' thinking approach, beyond single-farm scales [21]. [66] underlined the importance of features like hedgerows in diversifying habitats associated with many farmland bird benefits. [67] proposed that the best option for birds in winter are the seed-rich habitats while in the summer structurally and floristically rich habitats. The results of this study would rather support the findings of [18] that highlighted the importance of the presence of suitable breeding habitats in mixed landscape for farmland birds. Furthermore, in our case, whether differences between spring and winter seed abundance are attributed to seed consumption of species with high significance to farmland bird diet needs further investigation. From this viewpoint, more thorough investigation of the relationship between the richness and abundance of bird fauna and the respective parameters of seeds is necessary in the future.

Seed-eating birds are important topsoil-seed consumers inferring quantitative and qualitative changes in soil seed bank, especially in winter when plants serving as food sources to avifauna are highly reduced, compared to spring in the same fields [65]. Conversely, seed predators also have a determining role in plant communities at landscape level by impacting the abundance of specific plants of their preference, thus inferring floristic variations even at areas that are distanced in the landscape [68]. Consequently, it could not be disregarded that reduced seed availability can be a limiting factor to wintering birds, a fact that highlights the importance of interspecific competition of avian communities [69]. As such, neither the preference of seed foragers for seeds of varied seed sizes of specific annual plant species at landscape patches is to be overlooked in current and future agro-ecological management [70] nor the importance of the minimum distance of available food-resource patches in the rural landscape [31].

In this respect, as [71] supported, the landscape heterogeneity may benefit generalist birds but may mean habitat loss and fragmentation for specialists, and therefore management should not include unique standalone measures. Fragmentation and land-use changes in rural landscape also influence the soil seed bank in terms of size and composition [72]. These, and the current study findings, highlight the importance of habitat provision for farmland birds during winter and breeding seasons [21].

Author Contributions: Conceptualization, A.V. and A.S.; methodology A.V. and A.S.; software, A.V. and E.C.; validation, A.V., E.C. and A.S.; formal analysis, E.C.; data curation, E.C.; writing-original draft preparation, A.V., E.C. and A.S.; writing-review and editing, E.C. and A.S.; visualization, E.C.; supervision, A.S. All authors have read and agreed to the published version of the manuscript.

Funding: This research received no external funding.

Data Availability Statement: Data available on request from the authors.

Acknowledgments: The authors would like to particularly acknowledge the contribution of Martin Hermy, at KU Leuven, for his critical review comments on a previous version of this manuscript. Special appreciation to Michał Czyż, at Coding Manatee Ninja, for advice and verification of the data analyses conducted. We also wish to thank the reviewers for their improvements on a previous version of this manuscript.

Conflicts of Interest: The authors declare no conflict of interest. 


\section{Appendix A}

Table A1. Presence (+), total species richness and phenology of 61 herb-layer non-cultivated species of 25 families (11 grasslike species and 50 broadleaf (4 legumes and 46 forbs) herb-layer species) in Cereals, Maize, Clover, and Tillage in Dolichi plain during the growing season of 2006 (from [38]).

\begin{tabular}{|c|c|c|c|c|c|c|c|}
\hline \multirow[b]{2}{*}{ Family } & \multirow[b]{2}{*}{ Plant Species } & \multicolumn{2}{|c|}{ Phenology * } & \multicolumn{4}{|c|}{ Habitat } \\
\hline & & $\begin{array}{l}\text { Life- } \\
\text { Cycle }\end{array}$ & BG (Life-Form) & Cereals & Maize & Tillage & Clover \\
\hline \multirow[t]{10}{*}{ Poaceae } & Alopecurus myosuroides & $\mathrm{A}$ & G (The) & + & & & \\
\hline & Avena spp. & $\mathrm{A}$ & G (The) & + & & & \\
\hline & Bromus tectorum & A & G (The) & & & & + \\
\hline & Bromus spp. & $\mathrm{A}$ & G (The) & + & & & \\
\hline & Cynodon dactylon & $\mathrm{P}$ & $\begin{array}{c}\mathrm{G} \\
\text { (The/Geo/Hem) }\end{array}$ & + & + & + & \\
\hline & Hordeum murinum & A & $\mathrm{G}$ & & + & & + \\
\hline & Lolium multiflorum & $\mathrm{A}$ & G (The) & + & & & \\
\hline & Lolium rigidum & $\mathrm{A}$ & G & + & + & & + \\
\hline & Phalaris brachystachys & $\mathrm{A}$ & G & + & & & \\
\hline & Sorghum halepense & A & $\begin{array}{c}\mathrm{G} \\
\text { (Cha/Geo/The) }\end{array}$ & & + & & \\
\hline Cyperaceae & Cyperus glomeratus & A or $P$ & $G($ The $)$ & + & & & \\
\hline \multirow[t]{2}{*}{ Amaranthaceae } & Amaranthus blitoides & A & F (The) & & + & + & \\
\hline & Amaranthus retroflexus & $\mathrm{A}$ & F (The) & & + & + & \\
\hline \multirow[t]{9}{*}{ Asteraceae } & Anthemis altissima & A & F (Pha) & & & & + \\
\hline & Anthemis arvensis & A & F (Pha) & + & & & + \\
\hline & Sonchus arvensis & $\mathrm{P}$ & $\mathrm{F}(\mathrm{Geo})$ & + & + & + & + \\
\hline & Sonchus asper & $A$ or $B$ & F (Hem/The) & + & & + & \\
\hline & Sonchus oleraceus & WA & F (The) & + & + & + & + \\
\hline & Taraxacum officinale & WA & $\mathrm{F}(\mathrm{Cha} / \mathrm{Hem})$ & + & & & + \\
\hline & Tragopogon longifolius & $\mathrm{P}$ & $\mathrm{F}$ & + & & & \\
\hline & Tragopogon pratensis & $\mathrm{B}$ & $\mathrm{F}$ & & & & + \\
\hline & Xanthium spinosum & A & F (The) & & + & & \\
\hline \multirow[t]{3}{*}{ Apiaceae } & Bifora radians & $\mathrm{A}$ & $\mathrm{F}$ & + & + & & \\
\hline & Caucalis platycarpos & $\mathrm{A}$ & F (The) & + & & & \\
\hline & Scandix pecten-veneris & $\mathrm{A}$ & F (The) & + & & & \\
\hline \multirow[t]{2}{*}{ Boraginaceae } & Echium italicum & $\mathrm{B}$ & $\mathrm{F}$ & + & & & \\
\hline & Lithospermum arvense & A & F (The) & & + & & \\
\hline \multirow[t]{5}{*}{ Brassicaceae } & $\overline{\text { Capsella bursa-pastoris }}$ & $\mathrm{A}$ & F (Hem/The) & & + & & \\
\hline & Cardaria draba & A & F (The) & + & & & \\
\hline & Neslia paniculata & A & F (Hem) & & & & + \\
\hline & Sisymbrium altissimum & A or B & F (The) & & & & + \\
\hline & Sisymbrium irio & A & F (The) & & + & & \\
\hline Campanulaceae & Legusia spegulum veneris & A & $\mathrm{F}$ & + & & & \\
\hline \multirow[t]{3}{*}{ Caryophyllaceae } & Agrostemma githago & A & F & + & & & \\
\hline & Dianthus armeria var. uniflorus & A or B & $\mathrm{F}$ & + & & & \\
\hline & Silene inflate & A & F (Cry/Hem) & + & & & \\
\hline Chenopodiaceae & Chenopodium album var. viride & A & F (The) & + & & + & \\
\hline Convolvulaceae & Convolvulus arvensis & $\mathrm{P}$ & F (The/Geo/Cli) & & + & + & \\
\hline Euphorbiaceae & Chrozophora tinctonia & A & $\mathrm{F}$ (The) & & + & & \\
\hline \multirow[t]{4}{*}{ Fabaceae } & Lathyrus aphaca & A & L (The/ Cli) & & & & + \\
\hline & Trifolium striatum & A & L (Cha) & + & & & \\
\hline & Medicago spp. & A & L (Hem/The) & & & & + \\
\hline & Vicia spp. & A or $\mathrm{P}$ & L (The/Cli) & + & & & + \\
\hline \multirow[t]{2}{*}{ Fumariaceae } & Fumaria capreolata & A & $\mathrm{F}(\mathrm{Cli})$ & & & & + \\
\hline & Fumaria officinalis & $\mathrm{A}$ & $\mathrm{F}$ & + & & & + \\
\hline Geraniaceae & Geranium purpureum & $\mathrm{A}$ & F (The) & & & & \\
\hline Zygophyllaceae & Tribulus terrestris & A & F (The) & & + & & \\
\hline
\end{tabular}


Table A1. Cont.

\begin{tabular}{|c|c|c|c|c|c|c|c|}
\hline \multirow[b]{2}{*}{ Family } & \multirow[b]{2}{*}{ Plant Species } & \multicolumn{2}{|c|}{ Phenology* } & \multicolumn{4}{|c|}{ Habitat } \\
\hline & & $\begin{array}{l}\text { Life- } \\
\text { Cycle }\end{array}$ & BG (Life-Form) & Cereals & Maize & Tillage & Clover \\
\hline Lamiaceae & Lamium amplexicaule & A & F (The) & & + & & + \\
\hline Malvaceae & Malva sylvestris & $\mathrm{B}$ & F (Hem) & + & & & \\
\hline \multirow[t]{2}{*}{ Papaveraceae } & Papaver hybridum & A & F (The) & & & & \\
\hline & Papaver rhoeas & A & F (The) & + & + & & \\
\hline \multirow[t]{2}{*}{ Polygonaceae } & Bilderdykia convolvulus & A & F (The) & + & + & & \\
\hline & Polygonum aviculare & A & F (Cry /The) & + & + & & + \\
\hline Portulacaceae & Portulaca oleracea & A & F (The) & & + & & \\
\hline \multirow[t]{4}{*}{ Ranunculaceae } & Adonis aestivalis & A & $\mathrm{F}$ & + & & & + \\
\hline & Consolida regalis & A & $\mathrm{F}$ & + & & & \\
\hline & Delphinium orientale & A & $\mathrm{F}$ & + & & & \\
\hline & Ranunculus spp. & A & F (The/Hem) & + & & & \\
\hline Rubiaceae & Galium spp. & A & F (The) & + & + & & \\
\hline Scrophulariaceae & Veronica persica & A & F (The) & + & & & \\
\hline Solanaceae & Solanum nigrum & $\mathrm{P}$ & F (Hem/The) & & + & & \\
\hline Total num & pecies richness) of the or & sneci & er habitat: & 19 & 23 & 8 & 19 \\
\hline
\end{tabular}

* Phenological classes of herb-layer species: according to life cycle: $\mathrm{A}=$ Annual, $\mathrm{B}=\mathrm{Biennial}, \mathrm{P}=\mathrm{Perennial}$; according to biological group (BG): $\mathrm{G}=$ Grass, L = Legume, $\mathrm{F}=$ Forb, B = Bulbous (geophyte). Classification of plant life form in line with [73] in parenthesis: The = Therophyte; Hem = Hemicryptophyte; Pha = Phanerophyte; Cha = Chamaephyte; Cry = Cryptophyte; Cli = Climber. G: Cyperus is considered grass-like. Related background references: [54,74-77]. In bold are shown species of (least to highest) significance as food items to rural birds, while significant and highly significant species are besides underlined; classification followed [22,78,79], as well as field observations.

Table A2. Mean ( \pm Standard Deviation) above-ground variable estimations in the studied habitats [38]. Plant cover was recorded following [64]. The Field Physiognomy Index estimation followed [80].

\begin{tabular}{ccccc}
\hline Variable & 1 & \multicolumn{4}{c}{ Habitat } \\
\cline { 2 - 5 } & Cereals & Maize & Tillage & Clover \\
\hline $\begin{array}{c}\text { Field surface area (in habitat) } \\
\text { Field Physiognomy Index } \\
\text { \% bare soil }\end{array}$ & $19.75 \pm 3.46$ & $27.45 \pm 5.78$ & $20.32 \pm 3.95$ & $28.58 \pm 14.16$ \\
$\begin{array}{c}\text { Number of } \\
\text { non-cultivated species } \\
\text { \% plant cover of }\end{array}$ & $56.8 \pm 1.96$ & $94.3 \pm 0.76$ & $98 \pm 0.41$ & $76.3 \pm 2.04$ \\
$\begin{array}{c}\text { non-cultivated species } \\
\text { Num of species serving as } \\
\text { food items to birds }\end{array}$ & $33.8 \pm 1.84$ & $2.38 \pm 0.55$ & $1.82 \pm 0.4$ & $1.74 \pm 0.47$ \\
$\begin{array}{c}\text { \% plant cover of species serving } \\
\text { as food items to birds } \\
\text { \% plant cover of }\end{array}$ & $25.9 \pm 1.76$ & $0.19 \pm 0.11$ & $1.01 \pm 0.31$ & $0.01 \pm 0$ \\
$\quad$ cultivated species & $9.22 \pm 0.88$ & $3.32 \pm 0.33$ & $0.21 \pm 0.1$ & $22 \pm 1.97$ \\
\hline
\end{tabular}

${ }^{1}$ Species richness of non-cultivated species and of species serving as food items to birds differ with habitat (physiognomy), with the highest values in cereals (1-way ANOVA; LSD; $p<0.001$; unpublished data from [38]).

Recordings were conducted using quadrat $\left(1 \mathrm{~m}^{2}\right)$ at sampling points of a plot diagonal (see also design in Table A4). The recorded variables were: 1 . The total number of noncultivated plant species. 2 . The percentage of the sampling plot area $\left(1 \mathrm{~m}^{2}\right)$ that is covered by non-cultivated plant species (\%) percent of non-cultivated plant cover). 3 . The number of plant species serving as food items (namely species producing seeds where birds feed on) to rural bird (food resources); this classification was based on [22,78,79] and observations in the field. 4 . The (\%) percentage of food items from the total surface non-cultivated plant cover serving as food items to rural birds (\%) percent of non-cultivated plant cover serving as foot item to birds. 5 . The (\%) percentage covered by each crop species (cereals, maize, clover and residue from the previous crop field for tillage), respectively, for cereals, maize, clover and tillage fields (\% plant cover of each crop species). 
Table A3. Bird species recorded in the study area (in bold exclusively or partially seed-eaters). *: The bird species experienced decline in Europe $[6,22] ; \mathrm{F}=$ farmland specialist, $\mathrm{W}=$ primarily woodland species that commonly use farmland [6].

\begin{tabular}{|c|c|c|c|c|c|}
\hline Bird Species & Habitat & $\begin{array}{l}\text { Bern Con- } \\
\text { vention }\end{array}$ & $\begin{array}{l}\text { 79/409 EC } \\
\text { Directive }\end{array}$ & SPEC & $\begin{array}{c}\text { Bonn } \\
\text { Convention }\end{array}$ \\
\hline Accipiter nisus & & II & & & \\
\hline Alauda arvensis * & $\mathrm{F}$ & III & $\mathrm{II} / 2$ & 3 & \\
\hline Anthus pratensis & & II & & & \\
\hline Athene noctua & & II & & 3 & \\
\hline Buteo buteo & & II & & & \\
\hline Carduelis cannabina * & $\mathrm{F}$ & II & & 4 & \\
\hline Carduelis carduelis * & $\mathrm{F}$ & II & & & \\
\hline Carduelis chloris & $\mathrm{F}$ & II & & 4 & \\
\hline Circus cyaneus & & II & I & & II \\
\hline $\begin{array}{l}\text { Coccothraustes } \\
\text { coccothraustes } \\
\text { Corvus corone }\end{array}$ & & II & & & \\
\hline Corvus monedula & $\mathrm{F}$ & & & 4 & \\
\hline Dendrocopos syriacus & & II & I & 4 & \\
\hline Emberiza cirlus & & II & & & \\
\hline Erithacus rubecula & W & II & & 4 & II \\
\hline Falco columbarius & & II & I & & \\
\hline Falco tinnunculus * & $\mathrm{F}$ & II & & 3 & II \\
\hline Fringilla coelebs & W & III & & 4 & \\
\hline Galerida cristata & & III & & 3 & \\
\hline \multicolumn{6}{|l|}{ Garrulus glandarius } \\
\hline Melanocorypha calandra & & II & I & 3 & \\
\hline Miliaria calandra * & $\mathrm{F}$ & III & & 4 & \\
\hline Parus major & $\mathrm{W}$ & II & & & \\
\hline \multicolumn{6}{|l|}{ Passer domesticus * } \\
\hline Passer montanus * & $\mathrm{F}$ & III & & & \\
\hline Phoenicurus ochruros & & II & & & \\
\hline Pluvialis apricaria & & III & $\mathrm{I}-\mathrm{II} / 2$ & & II \\
\hline Prunella modularis * & & II & & 4 & \\
\hline Streptopelia decaocto & & III & $\mathrm{II} / 2$ & & \\
\hline Sturnus vulgaris * & $\mathrm{F}$ & & & & \\
\hline Turdus merula * & W & III & $\mathrm{II} / 2$ & 4 & II \\
\hline Turdus philomelos* & $\mathrm{W}$ & III & $\mathrm{II} / 2$ & 4 & II \\
\hline
\end{tabular}

1. For the species listed in Annex II, states that have signed the treaty are required to take the necessary measures for the protection and conservation of these species and their habitats; for the species listed in Annex III, states that have signed the treaty are required to regulate the exploitation of wild fauna and prevent illegal means of capture and killing. 2. I: Species that will be subject of special conservation measures taking into account their habitat to ensure their survival and reproduction in the area of their dispersal; II/1: Species that can be hunted in the geographical sea and land where this Directive applies; II/2: Species that can be hunted only in the Member States, having regard to local laws. 3. 1: Species of global interest for their conservation; 2: Concentrated in Europe and with an unfavorable conservation status; 3 : Not concentrated in Europe, but with an unfavorable conservation status; 4: Concentrated in Europe and with a favorable conservation status; w: Category related to winter populations; 4 . I: Species with risk of total or at large extent extinction; II: Species that can benefit from the international cooperation for their conservation and management. 
Table A4. Summary of the studied fields, sampling plots and methods [38].

\begin{tabular}{|c|c|c|c|c|c|c|c|c|c|}
\hline Season & Sampling/Parameter & $\begin{array}{l}\text { Habitat (i.e., } \\
\text { Crop) }\end{array}$ & $\begin{array}{l}\text { Number } \\
\text { of Fields }\end{array}$ & $\begin{array}{c}\text { Area } \\
\text { (Hectares) }\end{array}$ & Replicates (R) & & Iaterials & & lods \\
\hline \multirow{8}{*}{$\begin{array}{l}\text { fall/winter } \\
2006\end{array}$} & \multirow[b]{4}{*}{ ii. } & cereals & 10 & 19.75 & 20 & \multirow{4}{*}{\multicolumn{2}{|c|}{ Quadrat $1 \times 1 \mathrm{~m}^{2}$}} & \multirow{4}{*}{\multicolumn{2}{|c|}{$\begin{array}{l}{[80]} \\
{[64]}\end{array}$}} \\
\hline & & clover & 6 & 17.15 & 20 & & & & \\
\hline & & tillage & 10 & 20.31 & 20 & & & & \\
\hline & & maize & 10 & 27.45 & 20 & & & & \\
\hline & \multirow{8}{*}{$\begin{array}{c}(\mathrm{b}) \\
\text { soil cores } \\
\text { sampling/soil seed } \\
\text { bank abundance \& } \\
\text { diversity }\end{array}$} & cereals & 6 & 19.75 & 10 & \multirow{8}{*}{\multicolumn{2}{|c|}{$\begin{array}{l}\text { Cylindrical } \\
\text { ring, } 1 \mathrm{~cm} \\
\text { high } \\
\text { Sweep } \\
\text { Squirrel }\end{array}$}} & \multirow{8}{*}{\multicolumn{2}{|c|}{ [64] }} \\
\hline & & clover & 3 & 17.15 & 10 & & & & \\
\hline & & tillage & 6 & 20.31 & 10 & & & & \\
\hline & & maize & 6 & 27.45 & 10 & & & & \\
\hline \multirow{4}{*}{ spring 2007} & & cereals & 4 & - & 10 & & & & \\
\hline & & clover & 3 & - & 10 & & & & \\
\hline & & tillage & 3 & - & 10 & & & & \\
\hline & & maize & 2 & - & 10 & & & & \\
\hline
\end{tabular}

Table A5. The total number of seeds per $\mathrm{m}^{2}$ estimated for each species of the topsoil seedbank in each studied habitat for winter (left columns) and spring (right columns), respectively.

\begin{tabular}{|c|c|c|c|c|c|c|c|c|c|}
\hline \multirow{3}{*}{ Family } & \multirow{3}{*}{ Plant Species } & \multicolumn{8}{|c|}{ Habitat } \\
\hline & & \multicolumn{2}{|c|}{ Cereals } & \multicolumn{2}{|c|}{ Maize } & \multicolumn{2}{|c|}{ Tillage } & \multicolumn{2}{|c|}{ Clover } \\
\hline & & Winter & Spring & Winter & Spring & Winter & Spring & Winter & Spring \\
\hline Amaranthaceae & Amaranthus albus * & - & 112.99 & 112.36 & $10,112.99$ & 56.18 & 112.99 & - & 1977.40 \\
\hline Amaranthaceae & Amaranthus blitoides * & 56.18 & - & - & - & 0.00 & 112.99 & 1629.21 & - \\
\hline Amaranthaceae & Amaranthus retroflexus $*, \neq$ & $10,224.72$ & 6271.19 & $28,146.07$ & $10,000.00$ & 3539.33 & 4124.29 & $12,078.65$ & $21,807.91$ \\
\hline Asteraceae & Lactuca serriola & - & - & - & - & - & - & 56.18 & - \\
\hline Asteraceae & Sonchus asper & - & - & 11123.60 & - & - & - & - & - \\
\hline Apiaceae & Aethusa cynapium * & 112.36 & 2316.38 & - & - & - & - & 0.00 & 4802.26 \\
\hline Apiaceae & Bifora radians * & 1460.67 & 112.99 & - & - & - & - & - & - \\
\hline Apiaceae & Torilis nodosa & - & - & 56.18 & - & - & - & - & - \\
\hline Boraginaceae & Lithospermum arvense * & 2415.73 & 8644.07 & 112.36 & 56.50 & 112.36 & - & 1910.11 & 338.98 \\
\hline Brassicaceae & Brassica juncea $*$ & 786.52 & 1186.44 & 1460.67 & 56.50 & 1235.96 & 169.49 & 449.44 & 1581.92 \\
\hline Brassicaceae & Brassica nigra & - & - & - & - & - & - & - & 1016.95 \\
\hline Brassicaceae & $\overline{\text { Brassica rapa }}$ & - & - & 617.98 & - & - & - & 280.90 & - \\
\hline Brassicaceae & Brassica sp. & - & - & - & - & 56.18 & - & - & - \\
\hline Brassicaceae & Camelina microcarpa * & - & 169.49 & 112.36 & - & - & - & - & 56.50 \\
\hline Brassicaceae & Capsella bursa-pastoris * & 112.36 & - & 56.18 & - & - & - & 280.90 & 56.50 \\
\hline Brassicaceae & Sinapis arvensis $*, \ddagger$ & 3483.15 & 790.96 & 2191.01 & 1468.93 & 3370.79 & 508.47 & 617.98 & 1186.44 \\
\hline Caryophyllaceae & Silene dioica $^{*, \ddagger}$ & 1348.31 & 2881.36 & 4438.20 & 903.95 & 1179.78 & 225.99 & 4438.20 & 1920.90 \\
\hline Caryophyllaceae & Stellaria media & - & - & - & - & - & 1468.93 & - & - \\
\hline Chenopodiaceae & Chenopodium album $*$ & $23,651.69$ & 8135.59 & $24,887.64$ & $14,689.27$ & $19,157.30$ & 3276.84 & $22,134.83$ & 6610.17 \\
\hline Chenopodiaceae & Chenopodium vulvaria * & 2134.83 & - & 393.26 & 2259.89 & 2303.37 & 1977.40 & 4213.48 & - \\
\hline Convolvulaceae & Ipomoea hederacea & - & - & - & - & - & - & 56.18 & - \\
\hline Euphorbiaceae & Chrozophora tinctoria & 168.54 & - & - & - & 56.18 & - & - & - \\
\hline Euphorbiaceae & Euphorbia spp. * & 1741.57 & 790.96 & 337.08 & - & 561.80 & - & 1460.67 & - \\
\hline Fabaceae & Juncus sp. * & 3707.87 & 1751.41 & - & - & 561.80 & - & - & - \\
\hline Fabaceae & Medicago mimina & 56.18 & - & - & - & - & - & - & - \\
\hline Fabaceae & Medicago sativa & - & - & - & - & - & - & 168.54 & - \\
\hline Fabaceae & Medicago polymorpha & 168.54 & - & - & - & 112.36 & - & - & - \\
\hline Geraniaceae & Geranium lucidum & 674.16 & - & 56.18 & - & - & - & 224.72 & - \\
\hline Geraniaceae & Geranium pusillum & 56.18 & - & - & - & - & - & - & - \\
\hline Lamiaceae & Lamium amplexicaule * & 112.36 & 1129.94 & 224.72 & - & 112.36 & - & 617.98 & 960.45 \\
\hline Malvaceae & Abutilon theophrasti * & - & 169.49 & 56.18 & 395.48 & - & 56.50 & - & - \\
\hline Malvaceae & Malva sylvestris & - & - & - & - & - & - & 112.36 & - \\
\hline Papaveraceae & Papaver rhoeas * & 3876.40 & 4124.29 & 2640.45 & - & 1348.31 & - & 393.26 & 1412.43 \\
\hline Plantaginaceae & Plantago lanceolata & - & - & - & - & - & - & 112.36 & - \\
\hline Poaceae & Alopecurus myosuroides & 168.54 & - & - & - & - & - & - & - \\
\hline Poaceae & Alopecurus pratensis & - & - & 56.18 & - & - & - & - & - \\
\hline Poaceae & Apera spica-venti & - & - & 337.08 & - & - & - & - & - \\
\hline Poaceae & Avena nuda & - & 5.00 & - & - & - & - & - & - \\
\hline Poaceae & Avena sterillis & 1011.24 & - & - & - & 224.72 & - & - & - \\
\hline Poaceae & Cynodon dactylon & 56.18 & - & - & - & - & - & - & - \\
\hline Poaceae & Digitaria sanguinalis * & - & 56.50 & 5112.36 & - & 337.08 & 3276.84 & - & 2824.86 \\
\hline Poaceae & $\overline{\text { Echinochloa crus-galli }}{ }^{*}$ & - & - & 674.16 & 112.99 & - & - & - & $16,045.20$ \\
\hline Poaceae & Zea mays & - & - & 1797.75 & - & - & - & - & - \\
\hline Poaceae & Panicum repens * & 561.80 & - & - & - & - & - & - & 56.50 \\
\hline Poaceae & Setaria pumila & 56.18 & 225.99 & 4213.48 & - & 280.90 & 1242.94 & 337.08 & 225.99 \\
\hline Poaceae & Setaria spp. ${ }^{*}$ & - & 56.50 & 1966.29 & - & 449.44 & 56.50 & - & - \\
\hline Poaceae & Sorghum halepence * & - & - & 4269.66 & 56.50 & - & - & - & - \\
\hline Poaceae & Triticum aestivum ${ }^{*}$ & 56.18 & 225.99 & - & - & 56.18 & - & - & - \\
\hline
\end{tabular}


Table A5. Cont.

\begin{tabular}{|c|c|c|c|c|c|c|c|c|c|}
\hline \multirow{3}{*}{ Family } & \multirow{3}{*}{ Plant Species } & \multicolumn{8}{|c|}{ Habitat } \\
\hline & & \multicolumn{2}{|c|}{ Cereals } & \multicolumn{2}{|c|}{ Maize } & \multicolumn{2}{|c|}{ Tillage } & \multicolumn{2}{|c|}{ Clover } \\
\hline & & Winter & Spring & Winter & Spring & Winter & Spring & Winter & Spring \\
\hline Polygonaceae & Bilderdykia convolvulus * & 6460.67 & 2542.37 & 786.52 & 395.48 & 730.34 & - & - & 169.49 \\
\hline Polygonaceae & Eriogonum racemon & - & - & - & - & - & - & 168.54 & - \\
\hline Polygonaceae & Polygonum aviculare ${ }^{* \ddagger}$ & $38,202.25$ & $35,593.22$ & $14,213.48$ & 903.95 & 6516.85 & 1129.94 & $16,629.21$ & 2937.85 \\
\hline Polygonaceae & $\overline{\text { Polygonum lapathifolium }}$ & - & - & - & - & 337.08 & - & - & - \\
\hline Polygonaceae & Polygonum persicaria & - & 56.50 & - & - & - & - & - & 56.50 \\
\hline Polygonaceae & Rumex sanguineus * & - & $10,677.97$ & 56.18 & - & - & 225.99 & - & - \\
\hline Polygonaceae & Rumex sp. ${ }^{*}$ & 56.18 & 169.49 & 112.36 & - & 617.98 & 56.50 & - & 56.50 \\
\hline Portulacaceae & Portulaca oleracea $*$, & 9662.92 & $19,491.53$ & 2921.35 & 734.46 & 898.88 & 564.97 & $10,224.72$ & 4519.77 \\
\hline Primulaceae & Anagallis arvensis & - & - & 1348.31 & - & - & - & - & - \\
\hline Rosaceae & Rubus spp. & 56.18 & - & 168.54 & - & 112.36 & - & - & - \\
\hline Ranunculaceae & Consolida regalis * & 1910.11 & 1186.44 & - & - & - & - & - & - \\
\hline Rubiaceae & Galium aparine * & 505.62 & 112.99 & 56.18 & - & 168.54 & - & - & - \\
\hline Scrophulariaceae & Veronica arvensis. & 56.18 & - & - & - & - & - & - & - \\
\hline Scrophulariaceae & Veronica hederifolia. & 56.18 & - & - & - & - & - & - & - \\
\hline Scrophulariaceae & Veronica persica * & $14,719.10$ & 6214.69 & 393.26 & - & 1460.67 & 225.99 & 3595.51 & 225.99 \\
\hline Solanaceae & Datura stramonium * & - & 112.99 & - & - & - & - & 337.08 & - \\
\hline Solanaceae & Solanum nigrum * & 224.72 & 960.45 & 898.88 & 338.98 & 1123.60 & 112.99 & 337.08 & - \\
\hline Zygophyllaceae & Tribulus terrestris & - & - & - & - & - & - & 56.18 & - \\
\hline
\end{tabular}

Out of the 66 identified species, 35 were commonly detected in both seasons (winter and spring) and are marked with an asterisk ${ }^{*}$ ); seven species found across all habitats and seasons are additionally shown with the double cross ( $)$ ) indicates absence. In bold are shown species of (least to highest) significance as food items to rural birds, while significant and highly significant species are besides $\underline{\text { underlined }}$ classification followed [22,78,79], and field observations.

\section{Appendix B}

List of sources used for seed and plant specimen identification.

Seed identification:

- $\quad$ Flood, R.J. and Gates, S.C., 1986. Seed Identification Handbook, Official Seed Testing Station. National Institute Agricultural Botany. Publishing, Cambridge, UK.

- Lola P., 2003. Weeds Weed-Herbicides. Fate and behavior in the environment. Publications Modern Education.

- Seed collection of the Weed Laboratory of Department of Agriculture Crop Production and Rural Environment. University of Thessaly. (Professor P. Lolas).

- Seeds collected in the field

- $\quad$ Plant specimen and seed collections

Websites:

- $\quad$ Scottish Crop Research Institute

- University of Abertay Dundee

- $\quad$ ASIS Arable Seed Identification System http: / / asis.scri.ac.uk/

- The Ohio State University. Department of Horticulture and Crop Science. Seed IDWorkshop

http:/ / www.oardc.ohio-state.edu/seedid/

- University of Missouri Extension. Missouri Weed Seeds. Department of Agronomy Fred Fishel Kevin Bradley

http:/ / extension.missouri.edu/explore/agguides/pests/ipm1023.htm

- $\quad$ Seeds of Success Collections at the Bend Seed Extractory

http:/ / www.nps.gov/plants/sos/bendcollections/index.htm

- $\quad$ The seed identification web page. Paleoethnobotany Project

http:/ / www.oldthingsforgotten.com/seeds/seeds.htm

- Visual Identification of Small Oilseeds and Weed Seed Contaminants Grain Biology Bulletin No. 3 
http:/ /www.grainscanada.gc.ca/Pubs/Grainbio/bulletin3/sows_03-e.htm Plant specimen identification:

- Kavvadas S., 1956. Illustrated Botany-Botanic Dictionary, Volumes 1-9. Pegasus Publications, Athens.

- Vardavaki M. Zouzouli D., 2003. Anatomy and Morphology of plants. Ziti, Thessaloniki.

- Lola P., 2003. Weeds Weed-Herbicides. Fate and behavior in the environment. Publications Modern Education.

- The growers weed identification Handbook. Collective work. Publisher University of California, Division of Agriculture and Natural Resources.

- Flowers of Greece and the Balkans, A field Guide. Collective work. Publisher Oxford University.

- Bonnier G., 1989. La Grande Flora En Couleurs, Volumes 1-2. Publications Delachaux et Niestle.

Websites (online databases):

- SRI Ilinois Council on food and Agricultural Research

http:/ / weedid.aces.uiuc.edu/

- United States Department of Agriculture

http:/ / plants.usda.gov / classification.html

- Weed Identification and Descriptions

http:/ / twig.tamu.edu/weedid.htm

- Utah State University extension. The weed web

http:/ / extension.usu.edu/weedweb/ident/ID.htm

- University of California, Agriculture and Natural Resources, Statewide IPM Program http://www.ipm.ucdavis.edu/PMG/WEEDS/low_amaranth.html

\section{References}

1. Sotherton, N.W. Land use changes and the decline of farmland wildlife: An appraisal of the set-aside approach. Biol. Conserv. 1998, 83, 259-268. [CrossRef]

2. Benton, T.G.; Vickery, J.A.; Wilson, G.D. Farmland biodiversity: Is habitat heterogeneity the key? Trends Ecol. Evol. 2003, 18, 182-188. [CrossRef]

3. Robinson, R.A.; Hart, J.D.; Holland, J.M.; Parrott, D. Habitat use by seed-eating birds: A scale-dependent approach. Ibis 2004, 146, 87-98. [CrossRef]

4. Pedersen, C.; Krøgli, S.V. The effect of land type diversity and spatial heterogeneity on farmland birds in Norway. Ecol. Indic. 2017, 75, 155-163. [CrossRef]

5. Römermann, C.; Dutoit, T.; Poschlod, P.; Buisson, E. Influence of former cultivation on the unique Mediterranean steppe of France and consequences for conservation management. Biol. Conserv. 2005, 121, 21-33. [CrossRef]

6. Chamberlain, D.E.; Fuller, R.J.; Bunce, R.G.H.; Duckworth, J.C.; Shrubb, M. Changes in the abundance of farmland birds in relation to the timing of agricultural intensification in England Wales. J. Appl. Ecol. 2000, 37, 771-788. [CrossRef]

7. Donald, P.F.; Pisano, G.; Rayment, M.D.; Pain, D.J. The Common Agricultural Policy, EU enlargement and the conservation of Europe's farmland birds. Agric. Ecosyst. Environ. 2002, 89, 167-182. [CrossRef]

8. Stephens, P.A.; Freckleton, R.P.; Watkinson, A.R.; Sutherland, W. Predicting the response of farmland bird populations to changing food supplies. J. Appl. Ecol. 2003, 40, 970-983. [CrossRef]

9. Vickery, J.A.; Bradbury, R.B.; Henderson, I.G.; Eaton, M.A.; Grice, P.V. The role of agri-environment schemes and farm management practices in reversing the decline of farmland birds in England. Biol. Conserv. 2004, 119, 19-39. [CrossRef]

10. Wretenberg, J.; Pärt, T.; Berg, Å. Changes in local species richness of farmland birds in relation to land-use changes and landscape structure. Biol. Conserv. 2010, 143, 375-381. [CrossRef]

11. Sálek, M.; Havlícek, J.; Riegert, J.; Nesporc, M.; Fuchs, R.; Kipson, M. Winter density habitat preferences of three declining granivorous farmland birds: The importance of the keeping of poultry dairy farms. J. Nat. Conserv. 2015, 24, 10-16. [CrossRef]

12. Calvi, G.; Campedelli, T.; Florenzano, T.G.; Rossi, P. Evaluating the benefits of agri-environment schemes on farmland bird communities through a common species monitoring programme. A case study in northern Italy. Agric. Syst. 2018, 160, 60-69. [CrossRef] 
13. Gayer, C.; Kurucz, K.; Fischer, C.; Tscharntke, T.; Batáry, P. Agricultural intensification at local and landscape scales impairs farmland birds, but not skylarks (Alauda arvensis). Agric. Ecosyst. Environ. 2019, 277, 21-24. [CrossRef]

14. Suarez-Seoane, S.; Osborne, P.E.; Baudry, J. Responses of birds of different biogeographic origins and habitat requirements to agricultural land abandonment in northern Spain. Biol. Conserv. 2002, 105, 333-344. [CrossRef]

15. Lewis-Phillips, J.; Brooks, S.; Sayer, C.D.; McCrea, R.; Siriwardena, G.; Axmacher, J.C. Pond management enhances the local abundance and species richness of farmland bird communities. Agric. Ecosyst. Environ. 2019, 273, 130-140. [CrossRef]

16. Stoate, C.; Beja, B.P.; Boatman, N.D.; Herzon, I. Ecological impacts of early 21st century agricultural change in Europe-A review. J. Environ. Manag. 2009, 91, 22-46. [CrossRef]

17. Stanton, R.L.; Morrissey, C.A.; Clark, R.G. Analysis of trends and agricultural drivers of farmland bird declines in North America: A review. Agric. Ecosyst. Environ. 2018, 254, 244-254. [CrossRef]

18. Tarjuelo, R.; Benítez-López, A.; Casas, F.; Martín, C.A.; García, J.T.; Vinuela, J.; Mougeot, F. Living in seasonally dynamic Farmland: The role of natural and semi-natural habitats in the movements and habitat selection of a declining bird. Biol. Conserv. 2020, 251, 108794. [CrossRef]

19. Perkins, A.J.; Whittingham, M.J.; Bradbury, R.B.; Wilson, J.D.; Morris, A.J.; Barnett, P.R. Habitat characteristics affecting use of lowland agricultural grassland by birds in winter. Biol. Conserv. 2000, 95, 279-294. [CrossRef]

20. Perkins, A.J.; Maggs, H.E.; Wilson, J.D. Winter bird use of seed-rich habitats in agri-environment schemes. Agric. Ecosyst. Environ. 2008, 126, 189-194. [CrossRef]

21. Redhead, J.W.; Hinsley, S.A.; Beckmann, B.C.; Broughton, R.K.; Pywell, R.F. Effects of agri-environmental habitat provision on winter and breeding season abundance of famrland birds. Agric. Ecosyst. Environ. 2018, 251, 114-123. [CrossRef]

22. Marshall, E.J.P.; Brown, V.K.; Boatman, N.D.; Lutman, P.J.W.; Squire, G.R.; Ward, L.K. The role of weeds in supporting biological diversity within crop fields. Weed Res. 2003, 43, 77-89. [CrossRef]

23. Butler, S.J.; Bradbury, R.B.; Whittingham, M.J. Stubble height affects the use of stubble fields by farmland birds. J. Appl. Ecol. 2005, 42, 469-476. [CrossRef]

24. Hancock, M.H.; Duffield, S.; Boyle, J.; Wilson, J.D. The effect of harvest method on cereal stubble use by seed-eating birds in a High Nature Value farming system. Agric. Ecosyst. Environ. 2016, 219, 119-124. [CrossRef]

25. McHugh, N.M.; Prior, M.; Grice, P.V.; Leather, S.R.; Holland, J.M. Agri-environmental measures and the breeding ecology of a declining farmland bird. Biol. Conserv. 2017, 212, 230-239. [CrossRef]

26. Scherner, A.; Melander, B.; Kudsk, P. Vertical distribution and composition of weed seeds within the plough layer after eleven years of contrasting crop rotation and tillage schemes. Soil Tillage Res. 2016, 161, 135-142. [CrossRef]

27. Lal, B.; Gautam, P.; Raja, R.; Tripathi, R.; Shahid, M.; Mohanty, S.; Panda, B.B.; Bhattacharyya, P.; Nayak, A.K. Weed seed bank diversity and community shift in a four-decade-old fertilization experiment in rice-rice system. Ecol. Eng. 2016, 86, 135-145. [CrossRef]

28. Hosseini, P.; Karimi, H.; Babaei, S.; Mashhadi, H.R.; Oveisi, M. Weed seed bank as affected by crop rotation and disturbance. Crop Prot. 2014, 64, 1-6. [CrossRef]

29. Santín-Montanyá, M.I.; Martín-Lammerding, D.; Zambrana, E.; Tenorio, J.L. Management of weed emergence and weed seed bank in response to different tillage, cropping systems and selected soil properties. Soil Tillage Res. 2016, 161, 38-46. [CrossRef]

30. Chamberlain, D.E.; Vickery, J.A.; Glue, D.E.; Robinson, R.A.; Conway, G.J.; Woodburn, R.J.W.; Cannon, A.R. Annual and seasonal trends in the use of garden feeders by birds in winter. Ibis 2005, 147, 563-575. [CrossRef]

31. Siriwardena, G.M.; Calbrade, N.A.; Vickery, J.A.; Sutherland, W.J. The effect of the spatial distribution of winter seed food resources on their use by farmland birds. J. Appl. Ecol. 2006, 43, 628-639. [CrossRef]

32. Siriwardena, G.M.; Stevens, D.K. Effects of habitat on the use of supplementary food by farmland birds in winter. Ibis 2004, 146, 144-154. [CrossRef]

33. Henderson, I.G.; Vickery, J.A.; Carter, N. The use of winter bird crops by farmland birds in lowland England. Biol. Conserv. 2004, 118, 21-32. [CrossRef]

34. Marshall, E.J.P.; West, T.M.; Kleijn, D. Impacts of an agri-environment field margin prescription on the flora and fauna of arable farmland in different landscapes. Agric. Ecosyst. Environ. 2006, 113, 36-44. [CrossRef]

35. Geiger, F.; de Snoo, G.R.; Berendse, F.; Guerrero, I.; Morales, M.B.; Onate, J.J.; Eggers, S.; Part, T.; Bommarco, R.; Bengtsson, J.; et al. Landscape composition influences farm management effects on farmland birds in winter: A pan-European approach. Agric. Ecosyst. Environ. 2010, 139, 571-577. [CrossRef]

36. Moreira, F.; Beja, P.; Morgado, R.; Reino, L.; Gordinho, L.; Delgado, A.; Borralho, R. Effects of field management and landscape context on grassland wintering birds in Southern Portugal. Agric. Ecosyst. Environ. 2005, 109, 59-74. [CrossRef]

37. Hyvönen, T.; Huusela-Veistola, E. Impact of seed mixture and mowing on food abundance for farmland birds in set-asides. Agric. Ecosyst. Environ. 2011, 143, 20-27. [CrossRef]

38. Voudouri, A. The Value of Agro-Ecosystems for Biodiversity Outside the Growing Season: Comparative Assessment of Crops in the Elassona Region. Master's Thesis, University of Thessaly, Volos, Greece, 2008; 113p.

39. R Core Team. R: A Language and Environment for Statistical Computing. R Foundation for Statistical Computing: Vienna, Austria. Available online: https:/ / www.R-project.org/ (accessed on 15 June 2021).

40. Bolker, B.; Robinson, D. Broom. Mixed: Tidying Methods for Mixed Models. R Package Version 0.2.6. 2020. Available online: https: / /CRAN.R-project.org/package=broom.mixed (accessed on 15 June 2021). 
41. Wickham, H.; François, R.; Henry, L.; Müller, K. Dplyr: A Grammar of Data Manipulation, R Package Version 1.0.6. 2021. Available online: https:/ /CRAN.R-project.org/package=dplyr (accessed on 15 June 2021).

42. Wickham, H. Ggplot2: Elegant Graphics for Data Analysis; Springer: New York, NY, USA, 2016.

43. Bates, D.; Maechler, M.; Bolker, B.; Walker, W. Fitting Linear Mixed-Effects Models Using lme4. J. Stat. Softw. 2015, 67, 1-48. [CrossRef]

44. Kuznetsova, A.; Brockhoff, P.B.; Christensen, R.H.B. lmerTest Package: Tests in Linear Mixed Effects Models. J. Stat. Softw. 2017, 82, 1-26. [CrossRef]

45. Venables, W.N.; Ripley, B.D. Modern Applied Statistics with, S, 4th ed.; Springer: New York, NY, USA, 2002; ISBN 0-387-95457-0.

46. Hothorn, T.; Bretz, F.; Westfall, P. Simultaneous Inference in General Parametric Models. Biom. J. 2008, 50, 346-363. [CrossRef]

47. Wickham, H. tidyr: Tidy Messy Data, R Package Version 1.1.3. 2021. Available online: https://CRAN.R-project.org/package= tidyr (accessed on 15 June 2021).

48. Ball, D.A. Weed seed bank response to tillage, herbicides, and crop rotation sequence. Weed Sci. 1992, 40, 654-659. [CrossRef]

49. Cunningham, H.M.; Bradbury, R.B.; Chaney, K.; Wilcox, A. Effect of non-inversion tillage on field usage by UK farmland birds in winter. Bird Study 2005, 52, 173-179. [CrossRef]

50. Shrestha, A. Weed Seed Banks and Their Role in Future Weed Management; UC Statewide IPM Program: Parlier, CA, USA, 2001.

51. Whittingham, M.J.; Devereux, C.L.; Evans, A.D.; Bradbury, R.B. Altering perceived predation risk food availability: Management prescriptions to benefit farmland birds on stubble fields. J. Appl. Ecol. 2006, 43, 640-650. [CrossRef]

52. Donald, P.F.; Sanderson, F.J.; Burfield, I.J.; van Bommel, F.P.J. Further evidence of continent-wide impacts of agricultural intensification on European farmland birds, 1990-2000. Agric. Ecosyst. Environ. 2006, 116, 189-196. [CrossRef]

53. Wilson, J.D.; Whittingham, M.J.; Bradbury, R.B. The management of crop structure: A general approach to reversing the impacts of agricultural intensification on birds. Ibis 2005, 147, 453-463. [CrossRef]

54. Zanin, G.; Otto, S.; Riello, L.; Borin, M. Ecological interpretation of weed flora dynamics under different tillage systems. Agric. Ecosyst. Environ. 1997, 66, 177-188. [CrossRef]

55. Ghersa, C.M.; Martínez-Ghersa, M.A. Ecological correlates of weed seed size and persistence in the soil under different tiling systems: Implications for weed management. Field Crops Res. 2000, 67, 141-148. [CrossRef]

56. Baskin, C.C.; Baskin, J.M. Seeds. Ecology, Biogeography, and Evolution of Dormancy and Germination; Academic Press: San Diego, CA, USA, 1998; 666p.

57. Field, R.H.; Benke, S.; Bádonyi, K.; Bradbury, R.B. Influence of conservation tillage on winter bird use of arable fields in Hungary. Agric. Ecosyst. Environ. 2007, 120, 399-404. [CrossRef]

58. Reuss, S.A.; Buhler, D.D.; Gunsolus, J.L. Effects of soil depth and aggregate size on weed seed distribution and viability in a silt loam soil. Appl. Soil Ecol. 2001, 16, 209-217. [CrossRef]

59. Conn, J.S. Weed seed bank affected by tillage intensity for barley in Alaska. Soil Tillage Res. 2006, 90, 156-161. [CrossRef]

60. Carter, M.R.; Ivany, J.A. Weed seed bank composition under three long-term tillage regimes on a fine sandy loam in Atlantic Canada. Soil Tillage Res. 2006, 90, 29-38. [CrossRef]

61. Orłowski, G.; Czarnecka, J. Winter diet of reed bunting Emberiza schoeniclus in fallow and stubble fields. Agric. Ecosyst. Environ. 2007, 118, 244-248. [CrossRef]

62. Marino, P.C.; Westerman, P.R.; Pinkert, C.; van der Werf, W. Influence of seed density and aggregation on post-dispersal weed seed predation in cereal fields. Agric. Ecosyst. Environ. 2005, 106, 17-25. [CrossRef]

63. Robinson, R.A.; Sutherland, W.J. The winter distribution of seed-eating birds: Habitat structure, seed density and seasonal depletion. Ecography 1999, 22, 447-454. [CrossRef]

64. Moorcroft, D.; Whittingham, M.J.; Bradbury, R.B.; Wilson, J.D. The selection of stubble fields by wintering granivorous birds reflects vegetation cover food abundance. J. Appl. Ecol. 2002, 39, 535-547. [CrossRef]

65. Marone, L.; Rossi, B.E.; De Casenave, J.L. Granivore impact on soil-seed reserves in the central Monte desert. Argentina Funct. Ecol. 1998, 12, 640-645. [CrossRef]

66. Broughton, R.K.; Chetcuti, J.; Burgess, M.D.; Gerard, F.F.; Pywell, R.F. A regional-scale study of associations between farmland birds and woody networks of hedgerows and trees. Agric. Ecosyst. Environ. 2021, 310, 107300. [CrossRef]

67. Vickery, J.A.; Feber, R.E.; Fuller, R.J. Arable field margins managed for biodiversity conservation: A review of food resource provision for farmland birds. Agric. Ecosyst. Environ. 2009, 133, 1-13. [CrossRef]

68. Orrock, J.L.; Levey, D.J.; Danielson, B.J.; Damschen, E.I. Seed predation not seed dispersal explains the landscape-level abundance of an early-successional plant. J. Ecol. 2006, 94, 838-845. [CrossRef]

69. Dunning, J.B.; Brown, J.H. Summer rainfall and winter sparrow densities: A test of the food limitation hypothesis. Auk 1982, 99, 123-129. [CrossRef]

70. Lortie, C.L.; Ganey, D.T.; Kotler, B.P. The effects of gerbil foraging on the natural seedbank and consequences on the annual plant community. Oikos 2000, 90, 399-407. [CrossRef]

71. Teillard, F.; Antoniucci, D.; Jiguet, F.; Tichit, M. Contrasting distributions of grassland and arable birds in heterogeneous farmlands: Implications for conservation. Biol. Conserv. 2014, 176, 243-251. [CrossRef]

72. Sanou, L.; Salvadogo, P.; Zida, D.; Thiombiano, A. Contrasting land use systems influence the soil seed bank composition and density in a rural landscape mosaic in West Africa. Flora 2019, 250, 79-90. [CrossRef]

73. Raunkiaer, C. The Life Form of Plants and Statistical Plant Geography; Clarendon Press: Oxford, UK, 1934. 
74. Alsherif, E.A.; Ayesh, A.M.; Rawi, S.M. Floristic composition, life form and chorology of plant life at Khulais region, Western Saudi Arabia. Pak. J. Bot. 2013, 45, 29-38.

75. Carni, A.; Matevski, V.; Silc, U.; Custerevska, R. Early spring ephemeral therophytic non-nitrophilous grasslands as a habitat of various species of Romulea in the southern Balkans. Acta Bot. Croat. 2014, 73, 107-129.

76. Mehrvarz, S.S.; Nodehi, M.A. A floristic study of the Sorkhankol Wildlife Refuge, Guilan Province. Iran. Caspian J. Environ. Sci. 2015, 13, 183-196.

77. Sultan-Ud-Din, A.H.; Haidar, A.; Hamid, A. Floristic composition and life form classes of district Shangla, Khyber Pakhtunkhwa, Pakistan. J. Biodivers. Environ. Sci. 2016, 8, 187-206.

78. Wilson, J.D.; Morris, A.J.; Arroyo, B.E.; Clark, S.C.; Bradbury, R.B. A review of the abundance and diversity of invertebrate and plant foods of granivorous birds in northern Europe in relation to agricultural change. Agric. Ecosyst. Environ. 1999, 75, 13-30. [CrossRef]

79. Holland, J.M.; Hutchison, M.A.S.; Smith, B.; Aebischer, N.J. A review of invertebrates and seed-bearing plants as food for farmland birds in Europe. Ann. Appl. Biol. 2006, 148, 49-71. [CrossRef]

80. Wilson, J.D.; Evans, J.; Browne, S.J.; King, J.R. Territory distribution breeding success of skylarks Alauda arvensis on organic intensive farmland in southern England. J. Appl. Ecol. 1997, 34, 1462-1478. [CrossRef] 